\title{
Back to the future in Chagas disease: from animal models to patient cohort studies, progress in immunopathogenesis research
}

\author{
Julio Scharfstein ${ }^{1}{ }^{+}$, Juliana de Assis Silva Gomes ${ }^{2}$, Rodrigo Correa-Oliveira ${ }^{2}$ \\ 'Instituto de Biofísica Carlos Chagas Filho, Universidade Federal do Rio de Janeiro, Rio de Janeiro, RJ, Brasil \\ ${ }^{2}$ Instituto de Pesquisa René Rachou-Fiocruz, Belo Horizonte, MG, Brasil
}

\begin{abstract}
Despite the wealth of information generated by trans-disciplinary research in Chagas disease, knowledge about its multifaceted pathogenesis is still fragmented. Here we review the body of experimental studies in animal models supporting the concept that persistent infection by Trypanosoma cruzi is crucial for the development of chronic myocarditis. Complementing this review, we will make an effort to reconcile seemingly contradictory results concerning the immune profiles of chronic patients from Argentina and Brazil. Finally, we will review the results of molecular studies suggesting that parasite-induced inflammation and tissue damage is, at least in part, mediated by the activities of trans-sialidase, mucin-linked lipid anchors (TLR2 ligand) and cruzipain (a kinin-releasing cysteine protease). One hundred years after the discovery of Chagas disease, it is reassuring that basic and clinical research tends to converge, raising new perspectives for the treatment of chronic Chagas disease.
\end{abstract}

Key words: cardiomyopathy - Chagas disease - T cells - Trypanosoma cruzi

Tryanosoma cruzi is a taxon composed of genetically diversified subpopulations of clonal origin in the order Kinetoplatida. Operationally referred as T. cruzi strains or isolates, these parasites display marked phenotypic variability, with different multiplication rates, tissue tropisms and susceptibilities to drug treatment (Zingales et al. 1999, Macedo et al. 2002). In the late 1970s, Michael Miles and co-workers described zymodeme differences in parasites isolated from domestic (Z2) versus sylvatic (Z1/Z3) transmission cycles (Miles et al. 1978). After refinement of zymodeme classification (Tibayrenc \& Ayala 1987), the usage of probes for the 24S alpha RNA ribosomal sequences (rRNA) and the highly conserved mini-exon gene (Souto \& Zingales 1993, Souto et al. 1996) established that the $T$. cruzi species were derived from two main filogenetic ancestral lineages, which diverged 10-40 million years ago (Briones et al. 1999). Isolates bearing the genotypic markers corresponding to zymodemes Z1 and Z2, now referred to as Tc1 and TcII, circulate predominantly in the sylvatic and domestic cycles, respectively. It was subsequently found that $T$. cruzi II can be subclassified into five groups, designated IIa to IIe (Brisse et al. 2000). More recently, a third ancestor lineage (TcIII) was also characterised (De Freitas et al. 2006).

Renewed efforts were made to determine if infection by the major parasite lineages is associated with particular clinical forms of Chagas disease. For reasons that

Financial support: CNPq, FAPERJ, FAPEMIG

+ Corresponding author: scharf@biof.ufrj.br

Received 20 May 2009

Accepted 17 June 2009 are still unclear, studies in North and Central America have linked chronic chagasic myocardiopathy (CARD) to infection with the TcI lineage (Añez et al. 2004, RuízSánchez et al. 2005) whereas members of the TcII lineage were associated with heart disease in the Southern Cone of South America (Solari et al. 2001, Coronado et al. 2006). In another report, the reactivation of cerebral forms of Chagas disease in a patient with HIV/AIDS (Burgos et al. 2005) was associated with T. cruzi clones of the TcIIb group, whereas congenital Chagas disease was linked to infection by TcIId clones (Burgos et al. 2007). More recently, Venegas et al. (2009) investigated the association between $T$. cruzi clones belonging to the $\mathrm{TcI}$ and TcII lineages with the severity of cardiac disease. Using the Z-IIb (TcIIb) and Z-hybrid (TcIId and TcIIe) probes to characterise the genotypes of $T$. cruzi clones circulating in the peripheral blood of 37 chagasic patients, these workers found remarkably higher frequencies of Z-IIb T. cruzi clones in the group of noncardiac patients. In contrast, the distribution of sublineage Z-I clones was similar in both groups of patients. Based on these observations, Venegas et al. (2009) suggested that Z-IIb and Z-hybrid T. cruzi are efficiently cleared from cardiac tissues by potent immune effector responses. However, this clearance induces collateral heart immunopathology, at least in patients that are living in the Southern Cone of South America, which also suggests a relationship with host genetics. It remains to be determined whether Z-I clones and Z-IIb/Z-hybrid clones are equally competent in invading and thriving in cardiac tissues, and if so, whether these parasites are differentially susceptible to immune clearance by functionally distinct sets of $\mathrm{T}_{\mathrm{EM}}$ (Macedo \& Pena 1998, Andrade 1999, Vago et al. 2000). These are major points that have led researchers to evaluate if the development of chronic myocardiopathy relates to parasite persistence in heart tissues. 


\section{Tissue parasitism and chronic myocarditis in experi- mental models}

Several decades ago, pathologists were intrigued by the findings that myocardial specimens from chronic chagasic patients often displayed diffused inflammatory infiltrates and evidence of extensive fibrosis in heart tissues in spite of the fact that pseudocysts were rarely detected in such specimens (Andrade et al. 1994). In the mid 1970s, two alternative hypotheses were raised to account for these seemingly contradictory results. One school of thought suggested that microvascular lesions in the chronically infected myocardium might build up over the years, creating microcirculatory abnormalities that ultimately induce hypoxia, inflammation and fibrosis in susceptible chagasic patients (Rossi 1990, Morris et al. 1990, Mengel \& Rossi 1992). While not excluding a role for microvascular pathology, some groups contended that $T$. cruzi antigens might induce myocardial tissue damage and fibrosis through the activation of parasite-specific effector $\mathrm{T}$ cells. In contrast, the proponents of the autoimmunity hypothesis (Ribeiro-dosSantos \& Hudson 1981, Kierszenbaum 1986, Rizzo et al. 1989) argued that self-reactive (anti-heart) lymphocytes could account for the diffused inflammation and fibrosis observed in patients with severe chronic myocardiopathy. Ribeiro-dos-Santos et al. (1992) addressed this question using an animal model that closely resembled human CCM: Balb/C mice chronically infected with $T$. cruzi Colombiana. After developing a heterotypic ear model of syngeneic neonatal heart transplantation, these investigators demonstrated that adoptively transferred $\mathrm{CD}^{+} \mathrm{T}$ cells originating from chronically infected mice rejected the transplanted heart. Although the authors interpreted these findings as an indication that autoreactive $\mathrm{CD}^{+} \mathrm{T}$ cells promote chronic myocardiopathy (Ribeiro-dos-Santos et al. 1992), these conclusions were subsequently challenged by Tarleton et al. (1994); using two different experimental models, i.e., C5BL/6 and C3H mice infected with $T$. cruzi strains (Brazil, Y and Sylvio), these investigators showed that $\mathrm{T}$ cell-mediated rejection of neonatal heart depended on graft invasion by viable parasites. Although not formally excluding a secondary role for self-reactive T lymphocytes (Ribeirodos-Santos 2001, Soares et al. 2001, Girones \& Fresno 2003, Leon \& Engman 2003, Cunha-Neto et al. 2006), these observations suggested that development of chronic myocardiopathy might result from the collateral tissue damage and inflammation induced by IFN- $\gamma$ and TNF$\alpha$-producing anti-parasite effector T cells (Zhang \& Tarleton 1996, Tarleton 2003).

\section{TS antigens provide dominant epitopes for effector $\mathrm{CD8}^{+} \mathrm{T}$ cells}

Previously identified as surface targets of antibodies (Affranchino et al. 1989, Duthie et al. 2005), the polymorphic trans-sialidase (TS) antigens induce T cell responses in T. cruzi-infected or vaccinated mice as well as in chronic chagasic patients (Kahn \& Wleklinsky 1997, Wizel et al. 1997, 1998, Fujimura et al. 2001, Garg \& Tarleton 2002, Tzelepis et al. 2008). In an early study focusing on class II major histocompatibility complex (MHC)-restricted $\mathrm{CD}^{+} \mathrm{T}$ cell responses to TS antigens, Kahn and Wlekinski (1997) showed evidence that the simultaneous expression of individual antigens from the polymorphic TS family may limit the availability of processed epitopes from each protein antigen below the threshold level required to stimulate a protective IFN $\gamma$ response against the parasite. Years later, this issue was re-examined in light of indications that class I MHCrestricted effector $\mathrm{CD} 8^{+} \mathrm{T}$ cells targeting TS antigens are indispensable for the effective control of intracellular infection in vivo (Garg \& Tarleton 2002). Similar to the response to viruses and other pathogens that replicate in the host cell cytoplasm, T. cruzi proteins (amastigotes and trypomastigotes) released in the cytoplasm of infected host cells must undergo proteolytic processing by proteasomes before being transported from the cytoplasm to the endoplasmic reticulum, where they bind to MHC-class I molecules en route to the cell surface. In viral infection, it is well established that the cytotoxic $\mathrm{CD} 8^{+} \mathrm{T}$ cells usually kill infected host cells by targeting a few immunodominant epitopes. Given the far greater complexity of the eukaryotic T. cruzi genome $(12,000$ genes), immunologists initially argued that class I MHCrestricted epitopes were generated by the intracellular processing of a large number of parasite antigens. However, analysis of the TCR specificity of $\mathrm{CD}^{+} \mathrm{T}$ cells in mice and humans suggests that this is not the case: multiple studies suggest that immune clearance by the $\mathrm{CD} 8^{+}$ $\mathrm{T}$ cell subset is heavily dependent on recognition of TS epitopes (Wizel et al. 1997, Tzelepis et al. 2008). Using a panel of 324 peptides, 156 of which were derived from 1,430 TS genes in the annotated T. cruzi genome, Martin et al. (2006) identified $7 \mathrm{H} 2 \mathrm{~K}^{\mathrm{b}}$-restricted TS "immunodominant" epitopes that were capable of promptly eliciting IFN- $\gamma$ secretion and served as in vivo targets for cytolytic $\mathrm{CD} 8^{+} \mathrm{T}$ cells. Of note, subdominant specificities included epitopes from few non-TS proteins (e.g., cruzipain, mucin-associated surface proteins, $\beta$-galatosylfuranosyl transferase and GP63), all of which able to generate $\mathrm{HK}^{\mathrm{b}}$-restricted epitopes for $\mathrm{CD}^{+} \mathrm{T}$ cells. Notably, these non-TS peptides only elicited IFN- $\gamma$ responses (ELISPOT) ex vivo in $\mathrm{CD}^{+} \mathrm{T}$ cells from $40-60 \%$ of Brazil strain-infected B6 mice; furthermore, their frequencies were 4-20-fold lower as compared to those of $\mathrm{T}$ cells recognising TS epitopes, whether measured in acutely or chronically infected mice. Also noteworthy, the non-TS peptides were only capable of eliciting type-1 cytokine secretion after overnight incubation with $\mathrm{CD} 8^{+}$ $\mathrm{T}$ cells, while the immunodominant TS peptides elicited secretion of the type 1 cytokine after $5 \mathrm{~h}$ of cultivation. Complementing their study, Martin et al. (2006) used peptide $/ \mathrm{K}^{\mathrm{b}}$ tetra-mers to compare the magnitude, kinetics and dominance patterns of $\mathrm{CD} 8^{+} \mathrm{T}$ cell responses in mice infected with the Brazil, Y and CL strains. In mice infected with the Brazil parasite strain, the kinetics of the dominant anti-TS-CD8 ${ }^{+} \mathrm{T}$ cell responses paralleled those of the tissue parasite load, i.e., it was low at early stage of infection, peaked at 19-24 days post-infection and decreased in the post-acute phase. Not surprisingly, the hierarchy of immunodominant TS epitopes 
recognised by effector $\mathrm{CD} 8^{+} \mathrm{T}$ cells was influenced by parasite strain, suggesting that the efficiency of parasite clearance in natural infection may vary for different parasite clones (Martin et al. 2006, Tzelepis et al. 2008). Although the mechanisms leading to the selection of immunodominant TS epitopes are unknown, a comparative analysis of the TCR repertoire of experienced $\mathrm{CD} 8^{+} \mathrm{T}$ cell responses in infected mice heterozygous for class I MHC molecules (Tzelepis et al. 2008) suggested that immunodominance of TS epitopes is established at the level of antigen-presenting cells (APCs), most likely due to interference/competition of TS dominant agonists on the loading of class I MHC binding by subdominant peptides, thus possibly analogous to mechanisms involved in the generation of class II MHC-restricted epitopes (Kahn \& Wleklinsky 1997). By focusing effector $\mathrm{CD} 8^{+} \mathrm{T}$ cell responses on a limited range of dominant TS epitopes, the immune system can efficiently reduce the massive parasite burden observed in the acute phase, bringing it down to levels that are compatible with host survival. Moreover, considering that naturally infected hosts are often infected by multiple parasite clones, stochastic expression of TS antigens by amastigotes and/or trypomastigotes may allow for parasite escape (Scharfstein \& Morrot 1999), hence driving the evolutionary diversification of TS family proteins (Martin et al. 2006).

Although the concept of immunodominance provides a useful framework for investigating the pathogenic role of subdominant $\mathrm{T}$ cell specificities during the post-acute and chronic stages of the natural infection (discussed further below), it is not obvious why TS-specific TC1 fail to clear the infection in mice experimentally infected by T. cruzi clones or by parasite strains (less heterogenous than in natural infection). Grisotto et al. (2001) addressed this question by examining the phenotype of $\mathrm{CD} 8^{+} \mathrm{T}$ cells in secondary lymphoid tissues of mice infected in laboratory settings. Their study revealed that TCR and CD8 molecules were downregulated in memory CD ${ }^{+}$ $\mathrm{T}$ cells isolated from the spleen but not in $\mathrm{CD} 8^{+} \mathrm{T}$ cells isolated from the draining lymph nodes of chronically infected mice. Notably, splenic $\mathrm{CD} 8^{+}$memory (resting) $\mathrm{T}$ cells cultivated with $T$. cruzi-infected macrophages were readily activated (secretion of type 1 cytokines), suggesting that the down-regulation of $\operatorname{TCR}(\alpha, \beta)$ and CD8 molecules does not hamper their capacity to control the infection. In a subsequent work, Leavey and Tarleton (2003) compared the functional status (ex-vivo cytolytic and IFN- $\gamma$ responses) of effector $\mathrm{CD} 8^{+} \mathrm{T}$ cells isolated from muscle tissues of mice chronically infected with $T$. cruzi with those retrieved from the spleen. These authors noted that effector $\mathrm{CD} 8^{+} \mathrm{T}$ cells trafficking through the muscle tissues were severely impaired, whereas the effector function of $\mathrm{CD} 8^{+} \mathrm{T}$ cells isolated from the spleen of the same chronically infected mice was preserved. It is still unclear how the muscle tissue damage/inflammation suppresses Tc1 function ex vivo in such a selective way. Since there is no evidence of overt intracellular parasite outgrowth in the heart of chronically infected mice, it is possible that effector/memory $\mathrm{CD}^{+} \mathrm{T}$ cells $\left(\mathrm{T}_{\mathrm{EM}}\right)$ recruited to the heart might transiently exert their cytolytic function. In other words, collateral tissue dam- age in muscle tissues might be minimised if the activity of Tc1 is subjected to tight temporal control. More recently, studies by Mariano et al. (2008) showed that regulatory $\mathrm{T}\left(\mathrm{CD} 4^{+} \mathrm{CD} 25^{+} \mathrm{GITR}^{+} \mathrm{Foxp}^{+}\right)$cells migrate into the heart of infected mice. Notably, these authors showed that treatment with anti-CD25 or anti-GITR resulted in increased mortality, while only anti-GITR enhanced tissue parasitism and inflammation, leading to increased frequencies of intracardiac $\mathrm{CD} 4^{+}, \mathrm{CD} 8^{+}$ and $\mathrm{CCR}^{+}$leukocytes as well as upregulated TNF- $\alpha$ production. Collectively, these studies suggest that $\mathrm{T}_{\text {reg }}$ signalling through GITR may have broad implications for the pathogenesis of Chagas disease, affecting heart inflammation, parasite replication and ultimately, host resistance against the infection.

More recently, Bustamante et al. (2008) investigated in greater detail how the memory $\mathrm{T}$ cell compartment is affected by $T$. cruzi persistence in tissues of chronically infected mice. Remarkably, they reported that parasite eradication through aggressive anti-parasite treatment (with benznidazole) leads to the re-emergence of central memory $\mathrm{CD}^{+} \mathrm{T}_{\text {cells }}\left(\mathrm{T}_{\mathrm{CM}}\right)$, a functional subset that possesses a higher protective capacity as compared to the dominant, but short-lived, $\mathrm{CD}^{+} \mathrm{T}_{\mathrm{EM}}$-like population of chronically infected mice. Another important inference derived from the above study was that long-term host exposure to $T$. cruzi does not lead to the exhaustion of the dominant $\mathrm{T}$ cell specificities, at least in the mouse model. Additional studies are required to determine if the depressed generation of $\mathrm{T}_{\mathrm{CM}}$ may reflect dysfunctions associated with parasitism of the thymus and/or secondary lymphoid tissues (De Meis et al. 2008).

\section{Role of CCR5 in the pathogenesis of experimental infection}

Chemokines are small, 8-11-kDa proteins that regulate the trafficking of leukocytes by binding to cognate seven transmembrane $\mathrm{G}$ protein-coupled receptors (GPCR) expressed at the surface of a variety of cells, including endothelial cells and leukocytes (Proudfoot 2002). In the past decade, studies in experimental models of T. cruzi infection have revealed that chemokines are produced by infected macrophages and by cardiomyocytes, both in vitro (Villalta et al. 1998, Machado et al. 2000) and in vivo (Talvani et al. 2000, Aliberti et al. 2001, Petray et al. 2002, Hardison et al. 2006). Studies on the role of CCR5, the receptor for the chemokines CCL3 (MIP1- $\alpha$ ), CCL4 and CCL5 (RANTES), are of particular interest in light of human studies showing that heart disease is attenuated in chagasic patients displaying a single point mutation in the CCR5 promoter, the association being linked to lower expression levels of CCR5 on their leukocytes (Calzada et al. 2001). Based on observations made in the $\mathrm{C} 3 \mathrm{H} / \mathrm{HeJ}$ model of infection, Marino et al. (2004) reported that $\mathrm{CD} 8^{+} \mathrm{T}$ cells expressing CCR 5 predominated in the heart inflammatory infiltrates. Interestingly, mice treated with CR1/CCR5 antagonist (Met-RANTES) displayed increased survival rates associated with decreased frequencies of intracardiac $\mathrm{CD}^{+}$and $\mathrm{CD}^{+}{ }^{+}$cells, diminished deposition of fibronectin in heart tissues and attenuated myocarditis. In 
another study, Machado et al. (2005) showed that CCR5 expression on $\mathrm{CD} 8^{+} \mathrm{T}$ cells was positively modulated by $T$. cruzi infection. Consistent with this observation, mRNA and protein for the CCR5 ligands CCL3, CCL4 and CCL5 were detected in the hearts of infected mice in association with $\mathrm{CD}^{+}$and $\mathrm{CD} 8^{+} \mathrm{T}$ cells. Analysis of the outcome of acute infection in CCR5-deficient C57Bl/6 mice showed that $\mathrm{T}$ cell migration to the heart was impaired, and these mice were susceptible to acute infection, implying that CCR5 and its ligands play a central role in the control of $\mathrm{T}$ cell influx in this mouse-inbred strain. Hardison et al. (2006) reported similar findings in acutely infected CCR5-deficient C57Bl/6 mice, but these mice were not refractory to chronic inflammation. In contrast to their results, Medeiros et al. (2009) recently reported that Met-RANTES ameliorated cardiac damage in mice chronically infected with the Colombian strain. Accordingly, Met-RANTES significantly decreased the numbers of intracardiac $\mathrm{CD} 4^{+} \mathrm{T}$ cells, without significantly affecting recruitment of $\mathrm{CD} 8^{+} \mathrm{T}$ and $\mathrm{F} 4 / 80^{+}$macrophages to the myocardium. In spite of the discrepant results generated by CCR5-deficient C57B1/6 mice, the results obtained after pharmacological intervention with Met-RANTES and patient cohort studies suggest that CCR5 may play an important role in chronic immunopathology.

\section{Functional characterisation of TS-specific $\mathrm{CD8}^{+} \mathrm{T}$ cells from chronic chagasic patients}

Although the research conducted in experimental models of Chagas disease strongly suggest that tissue parasitism is a prerequisite for the development of chronic myocardiopathy, the introduction of more sensitive techniques for parasite detection in human myocardial specimens, such as PCR, revealed that tissue parasitism was underestimated by classical histochemistry (Jones et al. 1993). The link between parasite persistence in tissues and disease activity was substantiated by studies showing that chronic patients displaying the CARD display parasite DNA in the heart, but not in oesophageal tissues, whereas reciprocally, the patients that exclusively develop gastrointestinal abnormalities showed the presence of parasite DNA in oesophageal tissues, but not in the heart (Jones et al. 1993, Vago et al. 1996). The conclusions of these studies were further substantiated by immunohistochemical analysis of chronic myocardium specimens showing a positive correlation between the density of mononuclear cell infiltration in the myocardium and presence of local depots of parasite antigens (Higuchi et al. 1997, Palomino et al. 2000, Benvenuti et al. 2008). While not excluding the contribution of IFN$\gamma$-producing $\mathrm{CD}^{+} \mathrm{T}$ cells and activated macrophages on the development of chronic myocarditis in humans, TNF- $\alpha$ - and IFN- $\gamma$-producing $\mathrm{CD} 8^{+} \mathrm{T}$ cells were identified as the predominant subset of mononuclear cells infiltrating the myocardium (Reis et al. 1993, Higuchi et al. 1997). Due to logistical obstacles, the analysis of the epitope specificity of intracardiac $\mathrm{CD}^{+} \mathrm{T}$ cells from CARD patients was limited to an isolated study, involving a small cohort of patients with CARD that bear the highly prevalent HLA-A0201 allele (Fonseca et al.
2005). According to this study, $\mathrm{CD} 8^{+} \mathrm{T}$ cell lines derived from the heart tissues of CARD patients recognised two non-TS proteins, i.e., the FL-160 and cruzipain (Fonseca et al. 2005). Given the difficulties in obtaining heart tissues from a large number of chagasic patients, immunologists sought to characterise the epitope specificity of $\mathrm{CD}^{+} \mathrm{T}$ cells by analysing the immune profiles of $\mathrm{T}$ cells from the patients' peripheral blood. Taking advantage of structural information obtained about TS antigens, Laucella et al. (2004) used tetramer staining and ELISPOT to characterise class I MHC-restricted peptides derived from ASP-1, ASP-2 and TSA-1, in patients bearing the highly prevalent HLA-A.21 allele. Patients from non-endemic areas displayed very low frequencies of IFN- $\gamma$-producing memory $\mathrm{CD} 8^{+} \mathrm{T}$ cells for TS peptides, although the frequencies of responses to HLAA201-restricted influenza peptides in these chagasic patients were fairly well preserved. As conceded by the authors, it was somewhat disappointing that severe CARD patients exhibited virtually undetectable responses to the TS peptides (Laucella et al. 2004). Notably, however, a markedly different response profile was found in HLA-A2.1-positive individuals that continued to live in areas of active transmission of $T$. cruzi: these chronic chagasic patients displayed fairly higher frequencies of $\mathrm{TS}$-specific $\mathrm{CD} 8^{+} \mathrm{T}$ cell responses as compared to those of patients from Buenos Aires (Laucella et al. 2004). The authors believed that these seemingly conflicting data were an indication that multiple exposures to parasites might account for the increased frequencies of TS-specific $\mathrm{CD}^{+} \mathrm{T}$ cells observed in patients living in this high transmission area. Considering that the spectrum of $T$. cruzi genotypes present in patients that have left endemic areas in the last 11-20 years might be narrower than those in area of active transmission (which may display more divergent TS epitopes), it will be useful to know if the $T$. cruzi organisms that are currently circulating in areas of active transmission may comprise TS sequences that are more closely related to the raw T. cruzi genome sequencing reads that were used to generate their peptide panel.

Given that TS peptides elicited poor responses in $\mathrm{CD} 8^{+} \mathrm{T}$ cells from the Buenos Aires cohort, additional assays were performed with parasite lysates (amastigotes). Although limited to a small number $(n=9)$ of patients, the amastigote lysates induced high-frequency type 1 responses by $\mathrm{CD}^{+}$and $\mathrm{CD} 8^{+} \mathrm{T}$ cells $(6 / 9 \mathrm{pa}-$ tients). Intriguingly, the $\mathrm{T}$ cell recall assays performed with patients with severe cardiac disease showed that amastigote lysates did not induce a high frequency of IFN- $\gamma$-producing T cells. However, there is a potential caveat in the design of $\mathrm{CD}^{+} \mathrm{T}$ cell recall assays performed with PBMCs stimulated by amastigote lysates, or for that matter, for the recall assays performed with epimastigote (Epi) extracts (Gomes et al. 2003, Laucella 2004, Souza et al. 2007): since we don't know how these soluble parasite Ags are cross-presented to class I MHC-restricted $\mathrm{CD}^{+} \mathrm{T}$ cells, it is possible that qualitative/quantitative differences in the APC function of cells present in peripheral blood might account for the seemingly discrepant response profiles of $\mathrm{CD} 8^{+} \mathrm{T}$ cells from indeterminate (IND) versus CARD patients. Al- 
ternatively, amastigotes may express TLRs (Ropert \& Gazzinelli 2007, Medeiros et al. 2007) that preferentially suppress cytokine signalling in APCs from CARD patients through the induction of SOCS proteins, a regulatory pathway that limits the extent of TLR signalling by inhibiting type-I IFN signalling (Baetz et al. 2004).

In an effort to circumvent the above-mentioned complications, Albareda et al. (2006) used Brazil-infected dendritic cells (DCs) to study the maturation and migratory properties of the memory $\mathrm{T}$ cell compartment of chagasic patients. Their data showed a significant increase in total $\mathrm{T}_{\mathrm{EM}}\left(\mathrm{CD}^{2} 5 \mathrm{RA}^{-} \mathrm{CCR}^{-}\right)$in subjects with mild heart disease as compared with uninfected controls. Furthermore, they found that T. cruzi-specific memory $\mathrm{CD}^{+} \mathrm{T}$ cells derived from patients with none or mild heart dysfunctions were enriched in early-differentiated $\left(\mathrm{CD} 27^{+} \mathrm{CD} 28^{+}\right)$cells that were more responsive (IFN- $\gamma$ production) than $\mathrm{T}$ cells from patients with more severe cardiac disease. Based on these findings, these authors proposed that persistent infection could lead to a gradual exhaustion of the responsive $\mathrm{CD} 8^{+} \mathrm{T}$ cell population. Although the results obtained by Albareda et al. (2006) suggested that there is a more general dysfunction in the $\mathrm{CD} 8^{+} \mathrm{T}$ memory compartment, the source of $\mathrm{T}$ cells (PBMCs) was depleted of monocytes to ensure that $\mathrm{Ag}$ presentation was strongly dependent on the ex vivo-infected DCs. According to earlier studies by Gomes et al. (2003), recently extended by Souza et al. (2007), the cytokine profile of $\mathrm{Ag}$-stimulated $\mathrm{T}$ cells from chronic patients is modulated by inflammatory and anti-inflammatory cytokines produced by infected monocytes. Notably, IND patients displayed a higher ratio of monocytes expressing IL-10 than TNF- $\alpha$ (Souza et al. 2007). Although the exposure of monocytes to live $T$. cruzi leads to an increase in the frequency of $\mathrm{CD} 80^{+}$monocytes irrespective of the clinical stage, monocytes from patients with the cardiac form display decreased frequencies and intensities of CD86 expression compared to infected monocytes from individuals with the indeterminate clinical form. Conversely, exposure of lymphocytes to T. cruzi-infected monocytes led to an increase in surface expression of CTL4 by T cells from IND, but not CARD, patients compared to normal control individuals. As will be discussed, Costa et al. (2009) have recently demonstrated an association between a functional IL-10 gene polymorphism (-1082G/A), which leads to lower expression levels of IL-10, and the worsening of cardiac function in chronic Chagas disease. Hence, it is conceivable that IL-10-secreting cells are underrepresented in the monocyte-depleted populations of PBMCs that Albareda et al. (2006) have used to measure memory T cell responses elicited by Brazil strain-infected DCs. Conversely, it is also possible that the depletion of TNF- $\alpha$ producing monocytes from the PBMCs of chronic chagasic patients (Buenos Aires cohort) might have reduced the T cell stimulatory properties of Brazil-infected DCs, hence accounting for the low responsiveness observed under these conditions. Although these systemic regulatory interactions may not necessarily occur in the infected heart, it is tempting to speculate that chronic heart pathology is influenced by the balance between TNF- $\alpha$ /
IL-10-producing macrophages and/or IL-10-producing $\mathrm{CD}^{+} \mathrm{FOXP}^{+}$regulatory $\mathrm{T}$ cells, recently identified in higher frequencies in IND patients (Araujo et al. 2007).

Although the above studies collectively appoint IL10 as a counter-modulator of chronic heart disease, it is still unclear if the $\mathrm{T}$ cell-dependent tissue damage is ultimately caused by parasite-specific $\mathrm{CD} 8^{+} \mathrm{T}$ cells and/or by $\mathrm{T}_{\mathrm{H}} 1 \mathrm{CD} 4^{+} \mathrm{T}$ cells. Focusing their analysis on the TCR specificity of $\mathrm{CD} 8^{+} \mathrm{T}$ cells, Alvarez et al. (2008) have recently conducted a large screen of TS peptides that bind to the six most common HLA supertypes, which cover one or more HLA allele in $95 \%$ of the human population irrespective of ethnicity. Their results indicated that the promiscuous TS-binding epitopes for HLA-A02, HLAA03 and HLA A24 are the primary targets of memory $\mathrm{CD}^{+} \mathrm{T}$ cells in chronic chagasic patients. Positive responses were detected in 13 out of 25 asymptomatic subjects. This approach suggested that a specific set of class I MHC-restricted peptides can be used to measure the frequency and functional activity of T. cruzi-specific $\mathrm{CD}^{+} \mathrm{T}$ cells in a wide range of chagasic patients (with different ethnic backgrounds) without having to conduct HLA typing. As pointed out by the authors, the frequencies of IL-2-secreting, TS-specific $\mathrm{CD} 8^{+} \mathrm{T}$ cells were markedly reduced in chronically infected patients. Considering that parasite load is extremely low in chronically infected individuals, the authors proposed that long-term parasite persistence may drive the parasite/ TS- specific T cell population towards the IL-2-deficient mono-functional IFN- $\gamma$-T cell-responsive profile, thus impairing the self-renewal capacity. $\mathrm{T}$ cell assays performed with amastigote lysates suggested that the frequencies of IL-2-secreting $\mathrm{CD} 4^{+} \mathrm{T}$ cells were likewise reduced. Longitudinal studies are required to determine if the IL-12 deficiency might differentially affect the $\mathrm{T}$ regulatory cell compartment $\left(\mathrm{CD} 4{ }^{+} \mathrm{FOXP} 3 \mathrm{~T}_{\text {reg }}\right.$ ) (Araujo et al. 2007) of IND and CARD patients.

\section{Cohort studies using Epi-Ag link $T_{H} 1$ responses to severity of heart disease}

Although the results from cohort studies performed with chagasic patients in Brazil, Guatemala and Argentina seemed conflicting, some of these discrepancies may be reconciled by considering the peculiarities of the experimental design used in different studies. For example, different sources of parasite antigens were used to stimulate peripheral blood $\mathrm{T}$ cells in vitro, while the Brazilian group used Epis (Epi, CL strain), the studies with the Argentinian cohorts involved amastigote lysates (Brazil strain), TS-derived peptides and T. cruzi (Brazil)-infected DCs (Gomes et al. 2003, Laucella et al. 2004, Albareda et al. 2006). Given that Epi (insect stage developmental form) do not express appreciable levels of the stage-specific TS antigens (e.g., ASP-1, ASP-2 and TSA-1), we may infer that the epitope specificity of Epi-stimulated $\mathrm{T}_{\mathrm{H}} 1$ cells studied in Minas Gerais (MG) are exclusively directed against cross-reactive structures present either in amastigotes/trypomastigotes (Gomes et al. 2003, Araujo et al. 2007, Souza et al. 2007). Considering that expression of TS proteins is developmentally regulated (i.e., these surface antigens are upregulated in 
trypomastigotes and amastigotes, but not in Epis), it is unlikely that TS specificities significantly contribute to the pool of $\mathrm{CD}^{+}$or $\mathrm{CD}^{+} \mathrm{T}$ cells activated by Epi lysates in studies reported by Gomes et al. (2003). Viewed against this background, the analysis of the T cell immune response profiles of the cohorts from the Brazilian study (MG) initially involved PBMCs derived from 131 patients, either grouped as IND (41 patients) or CARD (70). The recall assays involved Ag stimulation (Epi or Trypo) ex vivo (1-6 days). Kinetic studies revealed that, irrespective of the source of $\mathrm{Ag}$ stimuli used, IFN- $\gamma$ production by $\mathrm{CD}^{+} \mathrm{CD}^{+} \mathrm{T}$ cells started at day 3 and peaked at day 6 , while IL-10 production (by monocytes) had an early onset. Based on the levels of IFN- $\gamma$ production elicited by antigen-stimulated $\mathrm{CD} 4^{+} \mathrm{T}$ cells, it was possible to categorise the patients in high or low-responsiveness groups. Notably, high numbers of IFN- $\gamma$-producing T cells were found in $83 \%$ of CARD patients and $59 \%$ of the IND group. Interestingly, the low IFN- $\gamma$ production of IND patients was linked to upregulated frequencies of IL-10-producing monocytes, which were already detectable at earlier stages of the in vitro culture. The observation that monocytes derived from chronic chagasic patients showed upregulated secretion of IL-10, further validated by the recent work of Souza et al. (2007), supports the concept that IL-10 might counterbalance $\mathrm{T}_{\mathrm{H}} 1$ induced immunopathology in the hearts of IND patients. As already mentioned, the severity of cardiac function abnormalities in Chagas disease (Costa et al. 2009) was recently linked to the $1082 \mathrm{G} / \mathrm{A}$ polymorphism of the IL10 promoter (Turner et al. 1997a, b), of which the phenotype is low IL-10 production. In a recent study, Araujo et al. (2007) found that patients with the IND form of the disease display a higher percentage of $\mathrm{CD} 4^{+} \mathrm{CD} 25^{\text {high }}$ $\mathrm{T}$ cells expressing FOXP3 and IL-10 compared to the CARD form. In other recent study, D' Ávila et al. (2009) reported an imbalance between IFN- $\gamma$ and IL-10 levels in the sera of patients with the CARD form. Collectively, these studies suggest that upregulated expression of IL-10 by IND patients might effectively counterbalance IFN- $\gamma$ production by $\mathrm{Ag}$-stimulated $\mathrm{T}$ cells.

Admittedly, additional studies are required to substantiate the hypothesis that pathogenic $\mathrm{T}_{\mathrm{H}} 1$ clones might contribute to the development of chronic myocardiopathy. As previously documented, the recognition of cross-reactive Epi antigens by human $\mathrm{T}$ cells may likely include $\mathrm{CD}^{+} \mathrm{T}$ and $\mathrm{CD} 8^{+} \mathrm{T}$ cell clones that recognise subdominant (non-TS related) class II MHC and class I MHC-restricted epitopes from cruzipain (Arnholdt et al. 1993, Morrot et al. 1997, Fonseca et al. 2005), the major cysteine protease of T. cruzi (Cazzulo et al. 1997). Expressed by all developmental forms of T. cruzi (Scharfstein et al. 1986, Murta et al. 1990), cruzipain has an $\mathrm{N}$-terminal catalytic domain linked to a long and highly antigenic carboxy-terminal extension (GP25) (Scharfstein et al. 1983, 1985). Progress in the structural characterisation of the oligosaccharide chains revealed the presence of sulphated residues (Barbosa et al. 2005) that are essential for cruzipain recognition by $\operatorname{IgG}$ antibodies from the serum of chagasic patients (Acosta et al. 2008). Viewed against this background, it is possible that dif- ferences in clonal frequencies of B lymphocytes present in the peripheral blood of IND and CARD patients might affect the efficiency of BCR-driven internalisation and processing of cruzipain epitopes for class II MHCrestricted $\mathrm{CD}^{+} \mathrm{T}$ cells. Admittedly, additional cohort studies are required to characterise the TCR repertoire and frequency of $\mathrm{CD}^{+} \mathrm{T}_{\mathrm{H}} 1$ and $\mathrm{Tc} 1$ clones stimulated by Epi Ags in CARD and IND patients.

\section{Chemokine receptors discriminate $T_{E M}$ phenotypes in chagasic patients}

Although conceding that the peripheral blood-derived $\mathrm{T}$ cells, which are responsive to Epi-Ag, may not necessarily reach the myocardium, the demonstration of intracardiac $\mathrm{MCH}$-class I-restricted, cruzipain-specific $\mathrm{CD} 8^{+} \mathrm{T}$ cells in CARD patients displaying the HLA. A0201 allele (Fonseca et al. 2005) implies that $T$ cells with subdominant (i.e., non-TS) specificities are recruited to the damaged chagasic heart.

Given that chemokine receptors CXCR3 and CCR5 were previously defined as markers for type-1 inflammatory $\mathrm{T}$ cells in the peripheral blood of multiple sclerosis patients (Misu et al. 2001), Gomes et al. (2005) investigated the percentage of chemokine receptors/cytokines on $\mathrm{CD}^{+}$and $\mathrm{CD} 8^{+} \mathrm{T}$ cells from CARD and IND patients. The percentages of $\mathrm{CD}^{+}$and $\mathrm{CD} 8^{+} \mathrm{T}$ cells co-expressing CCR 5 and IFN- $\gamma$, CXCR 3 and IFN- $\gamma$ or CXCR 3 and TNF- $\alpha$ were higher in CARD than in IND individuals; on the other hand, the percentage of $\mathrm{CD}^{+}$or $\mathrm{CD} 8^{+} \mathrm{T}$ cells co-expressing CCR 3 and IL-10 or co-expressing CCR3 and IL-4 were lower in CARD individuals than in IND individuals. In addition, a significantly positive correlation between the expression of CCR5 or CXCR3 and IFN- $\gamma$ was observed in CARD individuals, contrasting with a significantly positive correlation between the expression of CCR3 and IL-4 and of CCR3 and IL-10 in IND patients. These results are consistent with the notion that excessive type-1 immune responses by CARD patients might favour development of chronic heart pathology.

\section{The pro-inflammatory role of extracellular T. cruzi}

In spite of evidence suggesting that tissue parasitism is a prerequisite for the development of chronic myocarditis, it is uncertain if parasite pro-inflammatory molecules play a crucial role in the determination of pathogenic outcome. During the chronic stage, the release of intracellular parasites (spontaneous host cell death and/ or resulting from CTL-mediated killing) must be a sporadic event, because the heart tissues are only scarcely parasitised. Once released in interstitial tissues, the extracellular amastigotes tend to cluster in the proximity of the primary infection foci. If viable, the amastigotes can eventually re-infect neighbouring host cells (Ley et al. 1988, Scharfstein \& Morrot 1999, Fernandes \& Mortara 2004). In contrast, the flagellated trypomastigotes rapidly move away from the primary foci of infection, hence spreading tissue parasitism. Early studies predicted that T. cruzi may induce cumulative microvascular lesions in the heart (Morris et al. 1990, Rossi 1990, Tanowitz et al. 1990), but the molecular mechanisms underlying heart vasculopathy in $T$. cruzi-infected animals remained elu- 
sive for many years. More recently, however, Tanowitz et al. (2005) presented evidence that myocardial up-regulation of endothelin-1 may contribute to the pathogenesis of Chagas disease. In another interesting finding, it was recently proposed that $T$. cruzi may modulate hostparasite equilibrium through the production of parasitederived thromboxane molecules (Ashton et al. 2007). In spite of progress made by the above-mentioned groups, it is still unclear how the parasites induce endothelin-1 and/or produce thromboxane and whether these effects are critical for the development of chronic myocardiopathy. Early efforts to understand the molecular basis of endothelial cell responses to $T$. cruzi focused on the desialylation, at that time attributed to TS enzymes (Libby et al. 1986). More recently, however, Dias et al. (2008) demonstrated that the recombinant (catalytically inactive) TS bound to endothelial cell-surface molecules containing endothelial $\alpha 2,3$-linked sialic acid, inducing $\mathrm{NF}-\kappa \mathrm{B}$ activation, expression of adhesion molecules and blocking endothelial cell apoptosis induced by growth factor deprivation. Noteworthy in this context, TS binding to endothelial cells may render these cells sensitive to antibody-mediated cellular cytotoxicity (ADCC), as originally proposed by Ribeiro-dos-Santos and Hudson (1981). Although ultrastructural studies performed in acutely infected animals suggested that ADCC may drive chagasic microangiopathy (Andrade et al. 1994), it remains to be determined if this mechanism may also account for the extensive cardiac microcirculatory abnormalities observed in the chronic stage of human infection (Higuchi et al. 1999, Tanowitz et al. 2005).

Given that the heart microcirculation of chronically infected animals is not easily accessible to intravital microscopy, Monteiro et al. (2006) studied the mechanisms linking parasite-induced interstitial oedema to $\mathrm{T}$ cell developmental pathways using the mouse model of subcutaneous infection (Monteiro et al. 2006, Schmitz et al. 2009). While activation of the complement system is classically associated with induction of the adaptive system, it was only recently recognised that the kinin proteolytic system is another example of a proteolytic web that modulates the adaptive branch of cellular immunity (Monteiro et al. 2006, 2008, Scharfstein et al. 2007). Classically viewed as vasoactive autacoids, the nonapeptides bradykinin (BK) and lysyl-bradykinin are released from a moiety of their parental glycoproteins, high or low-molecular-weight kininogens, by the action of tissue or plasma kallikrein. The characterisation of the major cysteine protease of $T$. cruzi as a microbial kinin-releasing enzyme ("kininogenase") (Del Nery et al. 1997) was the starting point of investigations that appointed a role for the kinin system in the immunopathogenesis of experimental Chagas disease (Monteiro et al. 2008, Scharfstein et al. 2008). Although soluble kininogens are not efficiently processed by cruzipain, the interactions of plasma-borne kininogens with sulphated glycosaminoglycans displayed at cell surfaces render the kinin-precursor molecules sensitive to proteolytic processing by cruzipain (Lima et al. 2002). Once liberated, kinins swiftly bind to the bradykinin $\mathrm{B}_{2}$ receptor $\left(\mathrm{B}_{2} \mathrm{R}\right)$, a GPCR subtype that is constitutively expressed by a wide range of cell types, including cardiomyocytes, endothelial cells and DCs (Aliberti et al. 2003, Monteiro et al. 2006). The long-range signalling activity of the released kinins is prevented by the action of kinin-degrading metallopeptidases, such as angiotensin converting enzyme and neutral endopeptidase. Alternatively, the kinin peptides released from kininogens are metabolised by carboxypeptidase $\mathrm{M} / \mathrm{N}$, generating the C-terminally truncated des-Arg-BK ligands of $\mathrm{B}_{1} \mathrm{R}$, a GPCR that is upregulated in inflamed/damaged tissues.

Studies performed earlier in this decade revealed that tissue culture trypomastigotes (TCTs) can invade a broad range of resting or activated non-phagocytic cells, respectively via the signalling of $\mathrm{B}_{2} \mathrm{R}$ (Scharfstein et al. 2000) or through the signalling of the inducible $\mathrm{B}_{1} \mathrm{R}$ pathway (Todorov et al. 2003). Although TCTs are also able to invade host cells through the signalling of alternative GPCR specificities (Andrade \& Scharfstein, unpublished observations), it is conceivable that the parasites may exploit the fact that $\mathrm{B}_{1} \mathrm{R}$ is upregulated in inflamed/injured tissues to opportunistically invade heart cells (Todorov et al. 2003). Whether or not it is acting as a parasite virulence factor, it is now well established that the proteolytic release of kinins in infected tissues has a profound impact on the mechanisms that integrate inflammation and innate/adaptive immunity (Scharfstein et al. 2007). Support for this concept came from analysis of the susceptible phenotype of $\mathrm{B}_{2} \mathrm{R}$-deficient mice acutely infected (i.p. route) by the $\mathrm{Dm} 28$ strain of T. cruzi (Dm28c) (Monteiro et al. 2008). Based on previous work (Aliberti et al. 2003, Monteiro et al. 2006), these authors predicted that kinins generated in infected peripheral and/or secondary lymphoid tissues might have acted as $\mathrm{T}_{\mathrm{H}} 1$-directing natural adjuvants, thereby coordinating the generation of immunoprotective T cells. Indeed, analysis of the cytokine profiles of anti-parasite $\mathrm{T}$ cell responses in the spleen and heart tissues revealed that $\mathrm{B}_{2} \mathrm{R}$-deficient $\mathrm{C} 57 \mathrm{Bl} / 6$ mice failed to generate high frequencies of immunoprotective IFN- $\gamma$ producing $\mathrm{CD}^{+}{ }^{+} \mathrm{T}$ and $\mathrm{CD} 8^{+}$effector T cells. Surprisingly, the $\mathrm{Ag}$-specific $\mathrm{CD}^{+} \mathrm{T}$ cells from susceptible $\mathrm{B}_{2} \mathrm{R}^{-/-}$mice secreted high levels of IL-17 (Monteiro et al. 2008). Analysis of the in vitro interaction of Dm28 TCTs with conventional CD11 $1^{+}$DCs (splenic) disclosed that the kinin "danger" signals released by cruzipain potently induce the maturation of immature DCs from wild-type mice, but not DCs isolated from $\mathrm{B}_{2} \mathrm{R}^{-/}$mice. Adoptive transfer of wild-type splenic CD11 ${ }^{+}$DCs into susceptible $\mathrm{B}_{2} \mathrm{R}^{-/-}$mice reverted the susceptible phenotype of the recipient mice, while rescuing their ability to generate high frequencies of immunoprotective (type-1) $\mathrm{T}$ cells and reciprocally suppressing IL-17 responses, at the expense of kinin system activation (Monteiro et al. 2008). In summary, these studies suggested that the parasites rely on cruzipain to liberate the $\mathrm{T}_{\mathrm{H}} 1$-directing kinin danger signal from plasma-borne kininogens diffusing through infected lymphoid and/or peripheral tissues (Scharfstein et al. 2007).

It is well established that tissue sentinel cells, such as mast cells and DCs, sense tissue injury and pathogen threat through alarm signals conveyed by endogenous 
signals and/or microbial signatures. Further insight on the mechanisms underlying the pro-inflammatory phenotype of TCTs came from a comparison of the dynamics of inflammation in wild-type versus TLR2, TLR4 and $\mathrm{B}_{2} \mathrm{R}$-deficient mice infected via the s.c route (Monteiro et al. 2006). As also documented in a more recent paper (Schmitz et al. 2009), Dm28c TCT induce interstitial oedema via an intricate mechanism involving sequential activation of TLR2, CXCR2 and $\mathrm{B}_{2} \mathrm{R}$. Using paw oedema responses as a read out for inflammation, Monteiro et al. (2006) showed that glycosylphosphatidylinositol-linked mucin (tGPI-mucin), a potent TLR2 ligand shed by TCTs (Almeida \& Gazzinelli 2001, Roppert \& Gazzinelli 2007), is rapidly "sensed" by innate sentinel cells (e.g., tissue resident macrophages) via TLR2 activation. Following the secretion of neutrophilattracting CXC chemokines (MIP-2/KC), the macrophages activate the endothelium/neutrophils, hence linking TLR2-dependent innate recognition of the pathogen to the CXR2/neutrophil-dependent inflammation, which in this model is manifested as a slight increase in vascular permeability (Schmitz et al. 2009). Owing to the diffusion of plasma proteins, the concentration of blood-borne kininogens (cruzipain substrate) suddenly rises in peripheral sites of infection. Further downstream, cruzipain liberates vasoactive kinins from kininogens, thus amplifying interstitial oedema through the sequential activation of the endothelium lining via $\mathrm{B}_{2} \mathrm{R}$ and $\mathrm{B}_{1} \mathrm{R}$ (Todorov et al. 2003, Schmitz et al. 2009). As documented by Monteiro et al. (2006), the rise in kinin levels in peripheral tissues converts immature DCs into IL-12-producing APCs, which migrate to draining LNs, where they subsequently activate $T$ cells, inducing and/or sustaining $\mathrm{T}_{\mathrm{H}} 1$ polarisation.

As discussed above, TCTs evoke interstitial oedema via mechanisms involving cooperate activation of the TLR2 and the kinin/B R pathway (Monteiro et al. 2008, Schmitz et al. 2009). It is presently unknown if parasite clones from the major filogenetic lineages express variable levels of tGPI-mucin (Nakayasu et al. 2009), other TLR ligands (Ouaissi et al. 2002, Mathieu-Daudé et al. 2007) and/or cruzipain isoforms (Lima et al. 2001). If so, parasite clones may display differential power to activate microvascular beds via the TLR2/CXCR2/cruzipain $>$ ki$\operatorname{nin} / \mathrm{B}_{2} \mathrm{R} / \mathrm{B}_{1} \mathrm{R}$ pathway. If true, we may also predict that such processes may account for differential rates of leukocyte transmigration through the endothelium. Under these hypothetical conditions, the parasites may directly modulate lymphocyte function through the lectin activity of TS molecules (Todeschini et al. 2002a, b) or down-modulate macrophage microbicidal function as result of internalisation of apoptotic neutrophils and/or lymphocytes (Freirede-Lima et al. 2000, Dos Reis et al. 2005). In either case, we may predict that the differential activation of endothelium/neutrophils via the TLR2 $>\mathrm{B}_{2} \mathrm{R} / \mathrm{B}_{1} \mathrm{R}$ axis may have an impact on the host-parasite equilibrium.

Future studies may determine if the vascular permeability increases induced by extracellular $T$. cruzi forms can lead to the rapid diffusion of anti-parasite and/or autoreactive $\operatorname{IgG}$ antibody specificities present in chagasic serum into extravascular cardiac tissues. Although sporad- ic, these events may render the heart conduction system more vulnerable to the pathological effects of serum $\operatorname{IgG}$ auto-antibodies, such as those that cross-react with the R13 tope of T. cruzi ribosomal protein P2 $\beta$ and the peptide ESDEARRCYN from the second extracellular loop of the human $\beta_{1}$-adreno receptors (Smulski et al. 2006).

\section{Conclusive remarks}

Although the multifactorial nature of pathogenic determinants of Chagas disease leaves no room for simpleminded conclusions, the body of literature reviewed in this article may provide readers with a reasonable perspective of the current trends and challenges of pathogenesis research. While the bulk of human and animal studies suggest that $T$ cell-dependent control of intracellular parasite outgrowth depends predominantly on the targeting of epitopes encoded by TS family genes, it is conceivable that the development of severe myocardiopathy may result from deficient regulation of type-1 effector $\mathrm{T}$ cells that recognise hitherto uncharacterised subdominant epitopes. Another promising line of research in immunopathogenesis relies on knowledge about the activation pathways that interconnect parasite-induced inflammation and innate/adaptive immunity. The dissection of the pro-inflammatory role of parasite factors, such as TS antigens, lipid anchors and proteolytic enzymes, provides a new framework for investigations of the impact of genetic diversification of T. cruzi clones on the pathogenic outcome.

\section{REFERENCES}

Acosta DM, Arnaiz MR, Esteva MI, Barboza M, Stivale D, Orlando UD, Torres S, Laucella SA, Couto AS, Duschak VG 2008. Sulfates are main targets of immune responses to cruzipain and are involved in heart damage in BALB/c immunized mice. Int Immunol 20: 461-470.

Affranchino JL, Ibañez CF, Luquetti AO, Rassi A, Reyes MB, Macina RA, Aslund L, Pettersson U, Frasch AC 1989. Identification of a Trypanosoma cruzi antigen that is shed during the acute phase of Chagas' disease. Mol Biochem Parasitol 34: 221-228.

Albareda MC, Laucella SA, Alvarez MG, Armenti AH, Bertochi G, Tarleton RL, Postan M 2006. Trypanosoma cruzi modulates the profile of memory $\mathrm{CD} 8^{+} \mathrm{T}$ cells in chronic Chagas' disease patients Int Immunol 18: 465-471.

Aliberti J, Viola JP, Vieira-de-Abreu A, Bozza PT, Sher A, Scharfstein J 2003. Cutting edge: bradykinin induces IL-12 production by dendritic cells: a danger signal that drives Th1 polarization. J Immunol 170: 5349-5353.

Aliberti JC, Souto JT, Marino AP, Lannes-Vieira J, Teixeira MM, Farber J, Gazzinelli RT, Silva JS 2001. Modulation of chemokine production and inflammatory responses in interferon-gammaand tumor necrosis factor-R1-deficient mice during Trypanosoma cruzi infection. Am J Pathol 158: 1433-1440.

Almeida IC, Gazzinelli RT 2001. Proinflammatory activity of glycosylphosphatidylinositol anchors derived from Trypanosoma cru$z i$ : structural and functional analyses. J Leukoc Biol 70: 467-477.

Alvarez MG, Postan M, Weatherly DB, Albareda MC, Sidney J, Sette A, Olivera C, Armenti AH, Tarleton RL, Laucella SA 2008. HLA class I-T cell epitopes from trans-sialidase proteins reveal functionally distinct subsets of $\mathrm{CD} 8^{+} \mathrm{T}$ cells in chronic Chagas disease. PLoS Negl Trop Dis 2: e288. 
Andrade SG 1999. Trypanosoma cruzi: clonal structure of parasite strains and the importance of principal clones. Mem Inst Oswaldo Cruz 94 (Suppl. I): 185-187.

Andrade ZA, Andrade SG, Correa R, Sadigursky M, Ferrans VJ 1994. Myocardial changes in acute Trypanosoma cruzi infection. Ultrastructural evidence of immune damage and the role of microangiopathy. Am J Pathol 144: 1403-1411.

Añez N, Crisante G, da Silva FM, Rojas A, Carrasco H, Umezawa ES, Stolf AM, Ramírez JL, Teixeira MM 2004. Predominance of lineage I among Trypanosoma cruzi isolates from Venezuelan patients with different clinical profiles of acute Chagas' disease. Trop Med Int Health 9: 1319-1326.

Araujo FF, Gomes JA, Rocha MO, Williams-Blangero S, Pinheiro VM, Morato MJ, Correa-Oliveira R 2007. Potential role of $\mathrm{CD} 4{ }^{+} \mathrm{CD} 25^{\mathrm{HIGH}}$ regulatory $\mathrm{T}$ cells in morbidity in Chagas' disease. Front Biosci 12: 2797-2806.

Arnholdt AC, Piuvezam MR, Russo DM, Lima AP, Pedrosa RC, Reed SG, Scharfstein J 1993. Analysis and partial epitope mapping of human $\mathrm{T}$ cell responses to Trypanosoma cruzi cysteinyl proteinase. J Immunol 151: 3171-3179.

Ashton AW, Mukherjee S, Nagajyothi FN, Huang H, Braunstein VL, Desruisseaux MS, Factor SM, Lopez L, Berman JW, Wittner M, Scherer PE, Capra V, Coffman TM, Serhan CN, Gotlinger K, Wu KK, Weiss LM, Tanowitz HB 2007. Thromboxane A2 is a key regulator of pathogenesis during Trypanosoma cruzi infection. J Exp Med 204: 929-940.

Baetz A, Frey M, Heeg K, Dalpke AH 2004. Suppressor of cytokine signaling (SOCS) proteins indirectly regulate Toll-like receptor signaling in innate immune cells. J Biol Chem 279: 54708-54715.

Barboza M, Duschak VG, Fukuyama Y, Nonami H, Erra-Balsells R, Cazzulo JJ, Couto AS 2005. Structural analysis of the N-glycans of the major cysteine proteinase of Trypanosoma cruzi. Identification of sulfated high-mannose type oligosaccharides. FEBS $J$ 272: 3803-3815.

Benvenuti LA, Roggério A, Freitas HF, Mansur AJ, Fiorelli A, Higuchi ML 2008. Chronic American trypanosomiasis: parasite persistence in endomyocardial biopsies is associated with highgrade myocarditis. Ann Trop Med Parasitol 102: 481-487.

Briones MR, Souto RP, Stolf BS, Zingales B 1999. The evolution of two Trypanosoma cruzi subgroups inferred from rRNA genes can be correlated with the interchange of American mammalian faunas in the Cenozoic and has implications to pathogenicity and host specificity. Mol Biochem Parasitol 104: 219-232.

Brisse S, Dujardin JC, Tibayrenc M 2000. Identification of six Trypanosoma cruzi lineages by sequence-characterised amplified region markers. Mol Biochem Parasitol 111: 95-105.

Burgos JM, Begher SB, Freitas JM, Bisio M, Duffy T, Altcheh J, Teijeiro R, Lopez Alcoba H, Deccarlini F, Freilij H, Levin MJ, Levalle J, Macedo AM, Schijman AG 2005. Molecular diagnosis and typing of Trypanosoma cruzi populations and lineages in cerebral Chagas disease in a patient with AIDS. Am J Trop Med Hyg 73: 1016-1018.

Burgos N, Hernandez-Reif M, Mendoza R, Castillo R 2007. Caregivers' perception of HIV-infected Dominican children's behavior. West Indian Med J 56: 42-47.

Bustamante JM, Bixby LM, Tarleton RL 2008. Drug-induced cure drives conversion to a stable and protective $\mathrm{CD} 8^{+} \mathrm{T}$ central memory response in chronic Chagas disease. Nat Med 14: 542-550.

Calzada JE, Nieto A, Beraún Y, Martín J 2001. Chemokine receptor CCR5 polymorphisms and Chagas' disease cardiomyopathy. Tissue Antigens 58: 154-158.
Cazzulo JJ, Stoka V, Turk V 1997. Cruzipain, the major cysteine proteinase from the protozoan parasite Trypanosoma cruzi. Biol Chem 378: 1-10.

Coronado X, Zulantay I, Reyes E, Apt W, Venegas J, Rodriguez J, Solari A, Sanchez G 2006. Comparison of Trypanosoma cruzi detection by PCR in blood and dejections of Triatoma infestans fed on patients with chronic Chagas disease. Acta Trop 98: 314-317.

Costa GC, da Costa Rocha MO, Moreira PR, Menezes CA, Silva MR, Gollob KJ, Dutra WO 2009. Functional IL-10 gene polymorphism is associated with Chagas disease cardiomyopathy. $J$ Infect Dis 199: 451-454.

Cunha-Neto E, Bilate AM, Hyland KV, Fonseca SG, Kalil J, Engman DM 2006. Induction of cardiac autoimmunity in Chagas heart disease: a case for molecular mimicry. Autoimmunity 39: 41-54.

D’Avila DA, Guedes PM, Castro AM, Gontijo ED, Chiari E, Galvão LM 2009. Immunological imbalance between IFN- $\gamma$ and IL-10 levels in the sera of patients with the cardiac form of Chagas disease. Mem Inst Oswaldo Cruz 104: 100-105.

De Freitas JM, Augusto-Pinto L, Pimenta JR, Bastos-Rodrigues L, Gonçalves VF, Teixeira SM, Chiari E, Junqueira AC, Fernandes O, Macedo AM, Machado CR, Pena SD 2006. Ancestral genomes, sex and the population structure of Trypanosoma cruzi. PLoS Pathog 2: e24.

De Meis J, Ferreira LM, Guillermo LV, Silva EM, Dosreis GA, Lopes MF 2008. Apoptosis differentially regulates mesenteric and subcutaneous lymph node immune responses to Trypanosoma cruzi. Eur J Immunol 38: 139-146.

Del Nery E, Juliano MA, Lima AP, Scharfstein J, Juliano L 1997. Kininogenase activity by the major cysteinyl proteinase (cruzipain) from Trypanosoma cruzi. J Biol Chem 272: 25713-25718.

Dias WB, Fajardo FD, Graça-Souza AV, Freire-de-Lima L, Vieira F, Girard MF, Bouteille B, Previato JO, Mendonça-Previato L, Todeschini AR 2008. Endothelial cell signalling induced by transsialidase from Trypanosoma cruzi. Cell Microbiol 10: 88-99.

Dos Reis GA, Freire-de-Lima CG, Nunes MP, Lopes MF 2005. The importance of aberrant T-cell responses in Chagas disease. Trends Parasitol 21: 237-243.

Duthie MS, Cetron MS, Van Voorhis WC, Kahn SJ 2005. Trypanosoma cruzi-infected individuals demonstrate varied antibody responses to a panel of trans-sialidase proteins encoded by SA85-1 genes. Acta Trop 3: 317-329.

Fernandes AB, Mortara RA 2004. Invasion of MDCK epithelial cells with altered expression of Rho GTPases by Trypanosoma cruzi amastigotes and metacyclic trypomastigotes of strains from the two major phylogenetic lineages. Microbes Infect 6: 460-467.

Fonseca SG, Moins-Teisserenc H, Clave E, Ianni B, Nunes VL, Mady C, Iwai LK, Sette A, Sidney J, Marin ML, Goldberg AC, Guilherme L, Charron D, Toubert A, Kalil J, Cunha-Neto E 2005. Identification of multiple HLA-A*0201-restricted cruzipain and FL-160 CD $8^{+}$epitopes recognized by T cells from chronically Trypanosoma cruzi-infected patients. Microbes Infect 7: 688-697.

Fernandes AB, Mortara RA 2004. Invasion of MDCK epithelial cells with altered expression of Rho GTPases by Trypanosoma cruzi amastigotes and metacyclic trypomastigotes of strains from the two major phylogenetic lineages. Microbes Infect 6: 460-467.

Freire-de-Lima CG, Nascimento DO, Soares MB, Bozza PT, CastroFaria-Neto HC, de Mello FG, DosReis GA, Lopes MF 2000. Uptake of apoptotic cells drives the growth of a pathogenic trypanosome in macrophages. Nature 403: 199-203.

Fujimura AE, Kinoshita SS, Pereira-Chioccola VL, Rodrigues MM 2001. DNA sequences encoding $\mathrm{CD} 4^{+}$and $\mathrm{CD} 8^{+} \mathrm{T}$-cell epitopes 
are important for efficient protective immunity induced by DNA vaccination with a Trypanosoma cruzi gene. Infect Immun 69: $5477-5486$.

Garg N, Tarleton RL 2002. Genetic immunization elicits antigen-specific protective immune responses and decreases disease severity in Trypanosoma cruzi infection. Infect Immun 70: 5547-5555.

Girones N, Fresno M 2003. Etiology of Chagas disease myocarditis: autoimmunity, parasite persistence, or both? Trends Parasitol 19: 19-22.

Gomes JA, Bahia-Oliveira LM, Rocha MO, Busek SC, Teixeira MM, Silva JS, Correa-Oliveira R 2005. Type 1 chemokine receptor expression in Chagas' disease correlates with morbidity in cardiac patients. Infect Immun 73: 7960-7966.

Gomes JA, Bahia-Oliveira LM, Rocha MO, Martins-Filho OA, Gazzinelli G, Correa-Oliveira R 2003. Evidence that development of severe cardiomyopathy in human Chagas' disease is due to a Th1-specific immune response. Infect Immun 71: 1185-1193.

Grisotto MG, D’Império Lima MR, Marinho CR, Tadokoro CE, Abrahamsohn IA, Alvarez JM 2001. Most parasite-specific CD8 ${ }^{+}$ cells in Trypanosoma cruzi-infected chronic mice are downregulated for T-cell receptor-alphabeta and CD8 molecules. Immunology 102: 209-217.

Hardison JL, Wrightsman RA, Carpenter PM, Kuziel WA, Lane TE, Manning JE 2006. The CC chemokine receptor 5 is important in control of parasite replication and acute cardiac inflammation following infection with Trypanosoma cruzi. Infect Immun 74: $135-143$.

Higuchi MD, Ries MM, Aiello VD, Benvenuti LA, Gutierrez PS, Bellotti G, Pileggi F 1997. Association of an increase in CD8 ${ }^{+} \mathrm{T}$ cells with the presence of Trypanosoma cruzi antigens in chronic, human, chagasic myocarditis. Am J Trop Med Hyg 56: 485-489.

Higuchi ML, Fukasawa S, De Brito T, Parzianello LC, Bellotti G, Ramires JA 1999. Different microcirculatory and interstitial matrix patterns in idiopathic dilated cardiomyopathy and Chagas' disease: a three dimensional confocal microscopy study. Heart 82: $279-285$.

Jones EM, Colley DG, Tostes S, Lopes ER, Vnencak-Jones CL, McCurley TL 1993. Amplification of a Trypanosoma cruzi DNA sequence from inflammatory lesions in human chagasic cardiomyopathy. Am J Trop Med Hyg 48: 348-357.

Kahn SJ, Wleklinski M 1997. The surface glycoproteins of Trypanosoma cruzi encode a superfamily of variant T cell epitopes. J Immunol 159: 4444-4451.

Kierszenbaum F 1986. Autoimmunity in Chagas' disease. J Parasitol 72: 201-211.

Laucella SA, Postan M, Martin D, Hubby Fralish B, Albareda MC, Alvarez MG, Lococo B, Barbieri G, Viotti RJ, Tarleton RL 2004. Frequency of interferon-gamma-producing $\mathrm{T}$ cells specific for Trypanosoma cruzi inversely correlates with disease severity in chronic human Chagas disease. J Infect Dis 189: 909-918.

Leavey JK, Tarleton RL 2003. Cutting edge: dysfunctional CD8 ${ }^{+} \mathrm{T}$ cells reside in nonlymphoid tissues during chronic Trypanosoma cruzi infection. J Immunol 170: 2264-2268.

Leon JS, Engman DM 2003. The significance of autoimmunity in the pathogenesis of Chagas heart disease. Front Biosci 8: 15-22.

Libby P, Alroy J, Pereira ME 1986. A neuraminidase from Trypanosoma cruzi removes sialic acid from the surface of mammalian myocardial and endothelial cells. J Clin Invest 77: 127-135.

Lima AP, Almeida PC, Tersariol IL, Schmitz V, Schmaier AH, Juliano L, Hirata IY, Müller-Esterl W, Chagas JR, Scharfstein J 2002. Heparan sulfate modulates kinin release by Trypanosoma cruzi through the activity of cruzipain. $J$ Biol Chem 277 : 5875-5881.
Lima AP, dos Reis FC, Serveau C, Lalmanach G, Juliano L, Ménard R, Vernet T, Thomas DY, Storer AC, Scharfstein J 2001. Cysteine protease isoforms from Trypanosoma cruzi, cruzipain 2 and cruzain, present different substrate preference and susceptibility to inhibitors. Mol Biochem Parasitol 114: 41-52.

Macedo AM, Oliveira RP, Pena SD 2002. Chagas disease: role of parasite genetic variation in pathogenesis. Expert Rev Mol Med 4: 1-16.

Macedo AM, Pena SD 1998. Genetic variability of Trypanosoma cru$z i$ : implications for the pathogenesis of Chagas disease. Parasitol Today 14: 119-124.

Machado FS, Koyama NS, Carregaro V, Ferreira BR, Milanezi CM, Teixeira MM, Rossi MA, Silva JS 2005. CCR5 plays a critical role in the development of myocarditis and host protection in mice infected with Trypanosoma cruzi. J Infect Dis 191: 627-636.

Machado FS, Martins GA, Aliberti JC, Mestriner FL, Cunha FQ, Silva JS 2000. Trypanosoma cruzi-infected cardiomyocytes produce chemokines and cytokines that trigger potent nitric oxidedependent trypanocidal activity. Circulation 102: 3003-3008.

Mariano FS, Gutierrez FR, Pavanelli WR, Milanezi CM, Cavassani KA, Moreira AP, Ferreira BR, Cunha FQ, Cardoso CR, Silva JS 2008. The involvement of $\mathrm{CD} 4{ }^{+} \mathrm{CD} 25+\mathrm{T}$ cells in the acute phase of Trypanosoma cruzi infection. Microbes Infect 10: 825-833.

Marino AP, da Silva A, dos Santos P, Pinto LM, Gazzinelli RT, Teixeira MM, Lannes-Vieira J 2004. Regulated on activation, normal T cell expressed and secreted (RANTES) antagonist (MetRANTES) controls the early phase of Trypanosoma cruzi-elicited myocarditis. Circulation 110: 1443-1449.

Martin DL, Weatherly DB, Laucella SA, Cabinian MA, Crim MT, Sullivan S, Heiges M, Craven SH, Rosenberg CS, Collins MH, Sette A, Postan M, Tarleton RL 2006. CD8 ${ }^{+}$T-cell responses to Trypanosoma cruzi are highly focused on strain-variant transsialidase epitopes. PLoS Pathog 2: e77.

Mathieu-Daudé F, Bosseno MF, Garzon E, Lelièvre J, Sereno D, Ouaissi A, Brenière SF 2007. Sequence diversity and differential expression of Tc52 immuno-regulatory protein in Trypanosoma cruzi: potential implications in the biological variability of strains. Parasitol Res 101: 1355-1363.

Medeiros GA, Silvério JC, Marino AP, Roffê E, Vieira V, Kroll-Palhares K, Carvalho CE, Silva AA, Teixeira MM, Lannes-Vieira J 2009. Treatment of chronically Trypanosoma cruzi-infected mice with a CCR1/CCR5 antagonist (Met-RANTES) results in amelioration of cardiac tissue damage. Microbes Infect 11: 264-273.

Medeiros MM, Peixoto JR, Oliveira AC, Cardilo-Reis L, Koatz VL, Van Kaer L, Previato JO, Mendonça-Previato L, Nobrega A, Bellio M 2007. Toll-like receptor 4 (TLR4)-dependent proinflammatory and immunomodulatory properties of the glycoinositolphospholipid (GIPL) from Trypanosoma cruzi. J Leukoc Biol 82: 488-496.

Mengel JO, MA Rossi 1992. Chronic chagasic myocarditis pathogenesis: dependence on autoimmune and microvascular factors. $\mathrm{Am}$ Heart J 124: 1052-1057.

Miles MA, Souza A, Povoa M, Shaw JJ, Lainson R, Toye PJ 1978. Isozymic heterogeneity of Trypanosoma cruzi in the first autochthonous patients with Chagas' disease in Amazonian Brazil. Nature 272: 819-821.

Misu T, Onodera H, Fujihara K, Matsushima K, Yoshie O, Okita N, Takase S, Itoyama Y 2001. Chemokine receptor expression on T cells in blood and cerebrospinal fluid at relapse and remission of multiple sclerosis: imbalance of Th1/Th2-associated chemokine signaling. J Neuroimmunol 114: 207-212. 
Monteiro AC, Schmitz V, Morrot A, de Arruda LB, Nagajyothi F, Granato A, Pesquero JB, Müller-Esterl W, Tanowitz HB, Scharfstein J 2008. Bradykinin B2 receptors of dendritic cells, acting as sensors of kinins proteolytically released by Trypanosoma cruzi, are critical for the development of protective type-1 responses. PLoS Pathog 3: e185.

Monteiro AC, Schmitz V, Svensjo E, Gazzinelli RT, Almeida IC, Todorov A, de Arruda LB, Torrecilhas AC, Pesquero JB, Morrot A, Bouskela E, Bonomo A, Lima AP, Müller-Esterl W, Scharfstein J 2006. Cooperative activation of TLR2 and bradykinin B2 receptor is required for induction of type 1 immunity in a mouse model of subcutaneous infection by Trypanosoma cruzi. J Immunol 177: 6325-6335.

Morris SA, Tanowitz H, Wittner M, Bilezikian JP 1990. Pathophysiological insights into the cardiomyopathy of Chagas' disease. Circulation 82: 1900-1910.

Morrot A, Strickland DK, Higuchi Mde L, Reis M, Pedrosa R, Scharfstein J 1997. Human T cell responses against the major cysteine proteinase (cruzipain) of Trypanosoma cruzi: role of the multifunctional alpha 2-macroglobulin receptor in antigen presentation by monocytes. Int Immunol 9: 825-834.

Murta AC, Persechini PM, Padron Tde S, de Souza W, Guimarães JA, Scharfstein J 1990. Structural and functional identification of GP57/51 antigen of Trypanosoma cruzi as a cysteine proteinase. Mol Biochem Parasitol 43: 27-38.

Nakayasu ES, Yashunsky DV, Nohara LL, Torrecilhas AC, Nikolaev AV, Almeida IC 2009. GPIomics: global analysis of glycosylphosphatidylinositol-anchored molecules of Trypanosoma cruzi. Mol Syst Biol 5: 261.

Ouaissi A, Guilvard E, Delneste Y, Caron G, Magistrelli G, Herbault N, Thieblemont N, Jeannin P 2002. The Trypanosoma cruzi Tc52-released protein induces human dendritic cell maturation, signals via Toll-like receptor 2, and confers protection against lethal infection. J Immunol 168: 6366-6374.

Palomino SA, Aiello VD, Higuchi ML 2000. Systematic mapping of hearts from chronic chagasic patients: the association between the occurrence of histopathological lesions and Trypanosoma cruzi antigens. Ann Trop Med Parasitol 94: 571-579.

Petray P, Corral R, Meckert P, Laguens R 2002. Role of macrophage inflammatory protein-1alpha (MIP-1alpha) in macrophage homing in the spleen and heart pathology during experimental infection with Trypanosoma cruzi. Acta Trop 83: 205-211.

Proudfoot AEI 2002. Chemokine receptors: multifaceted therapeutic targets. Nat Rev Immunol 2: 106-115.

Reis DD, Jones EM, Tostes S, Gazzinelli G Colley DG, McCurley $T$ 1993. Characterization of inflammatory infiltrates in chonic chagasic myocardial lesions: presence of TNF-alpha ${ }^{+}$cells and dominance of Granzyme $\mathrm{A}^{+}, \mathrm{CD} 8^{+}$lymphocytes. Am J Trop Med Hyg 43: 637-644.

Ribeiro-dos-Santos R, Hudson L 1981. Denervation and the immune response in mice infected with Trypanosoma cruzi. Clin Exp Immunol 44: 349-354.

Ribeiro-dos-Santos R, Mengel JO, Postol E, Soares RA, FerreiraFernandez E, Soares MB, Pontes de Carvalho LC 2001. A heartspecific $\mathrm{CD} 4^{+} \mathrm{T}$-cell line obtained from a chronic chagasic mouse induces carditis in heart-immunized mice and rejection of normal heart transplants in the absence of Trypanosoma cruzi. Parasite Immunol 23: 93-101.

Ribeiro-dos-Santos R, Rossi MA, Laus JL, Silva JS, Savino W, Mengel J 1992. Anti-CD4 abrogates rejection and reestablishes long-term tolerance to syngeneic newborn hearts grafted in mice chronically infected with Trypanosoma cruzi. J Exp Med 175: 29-39.
Rizzo LV, Cunha-Neto E, Teixeira AR 1989. Autoimmunity in Chagas' disease: specific inhibition of reactivity of $\mathrm{CD}^{+} \mathrm{T}$ cells against myosin in mice chronically infected with Trypanosoma cruzi. Infect Immun 57: 2640-2644.

Ropert C, Gazzinelli RT 2007. Innate recognition, cell signaling and proinflammatory responses during infection with Trypanosoma cruzi. In EY Denkers, RT Gazzinelli (eds.), Protozoans in macrophages, Landes Biosciences, Austin, p. 49-66.

Rossi MA 1990. Microvascular changes as a cause of chronic cardiomyopathy in Chagas' disease. Am Heart J 10: 233-236.

Ruíz-Sánchez R, León MP, Matta V, Reyes PA, López R, Jay D, Monteón VM 2005. Trypanosoma cruzi isolates from Mexican and Guatemalan acute and chronic chagasic cardiopathy patients belong to Trypanosoma cruzi I. Mem Inst Oswaldo Cruz 100: 281-283.

Scharfstein J, Lima AP 2008. Roles of naturally occurring protease inhibitors in the modulation of host cell signaling and cellular invasion by Trypanosoma cruzi. Subcell Biochem 47: 140-154.

Scharfstein J, Luquetti A, Murta AC, Senna M, Rezende JM, Rassi A, Mendonça-Previato L 1985. Chagas' disease: serodiagnosis with purified Gp25 antigen. Am J Trop Med Hyg 34: 1153-1160.

Scharfstein J, Monteiro AC, Schmitz V, Svensjö E 2008. Angiotensinconverting enzyme limits inflammation elicited by Trypanosoma cruzi cysteine proteases: a peripheral mechanism regulating adaptive immunity via the innate kinin pathway. Biol Chem 389: 1015-1024

Scharfstein J, Morrot A 1999. A role for extracellular amastigotes in the immunopathology of Chagas disease. Mem Inst Oswaldo Cruz 94 (Suppl. I): 51-63.

Scharfstein J, Rodrigues MM, Alves CA, de Souza W, Previato JO, Mendonça-Previato L 1983. Trypanosoma cruzi: description of a highly purified surface antigen defined by human antibodies. J Immunol 131: 972-976.

Scharfstein J, Schechter M, Senna M, Peralta JM, Mendonça-Previato L, Miles MA 1986. Trypanosoma cruzi: characterization and isolation of a 57/51,000 m.w. surface glycoprotein (GP57/51) expressed by epimastigotes and bloodstream trypomastigotes. J Immunol 137: 1336-1341.

Scharfstein J, Schmitz V, Morandi V, Capella MM, Lima AP, Morrot A, Juliano L, Müller-Esterl W 2000. Host cell invasion by Trypanosoma cruzi is potentiated by activation of bradykinin $\mathrm{B}(2)$ receptors. J Exp Med 192: 1289-1300.

Scharfstein J, Schmitz V, Svensjö E, Granato A, Monteiro AC 2007. Kininogens coordinate adaptive immunity through the proteolytic release of bradykinin, an endogenous danger signal driving dendritic cell maturation. Scand J Immunol 66: 128-136.

Schmitz V, Svensjö E, Serra RR, Teixeira MM, Scharfstein J 2009. Proteolytic generation of kinins in tissues infected by Trypanosoma cruzi depends on CXC chemokine secretion by macrophages activated via Toll-like 2 receptors. J Leukoc Biol 85: 1005-1014.

Smulski C, Labovsky V, Levy G, Hontebeyrie M, Hoebeke J, Levin MJ 2006. Structural basis of the cross-reaction between an antibody to the Trypanosoma cruzi ribosomal P2beta protein and the human beta1 adrenergic receptor. FASEB J 20: 1396-1406.

Soares MB, Pontes-De-Carvalho L, Ribeiro-Dos-Santos R 2001. The pathogenesis of Chagas' disease: when autoimmune and parasitespecific immune responses meet. An Acad Bras Cienc 73: 547-559.

Solari A, Campillay R, Ortíz S, Wallace A 2001. Identification of Trypanosoma cruzi genotypes circulating in Chilean chagasic patients. Exp Parasitol 97: 226-233. 
Souto RP, Fernandes O, Macedo AM, Campbell DA, Zingales B 1996. DNA markers define two major phylogenetic lineages of Trypanosoma cruzi. Mol Biochem Parasitol 83: 141-152.

Souto RP, Zingales B 1993. Sensitive detection and strain classification of Trypanosoma cruzi by amplification of a ribosomal RNA sequence. Mol Biochem Parasitol 62: 45-52.

Souza PE, Rocha MO, Menezes CA, Coelho JS, Chaves AC, Gollob KJ, Dutra WO 2007. Trypanosoma cruzi infection induces differential modulation of costimulatory molecules and cytokines by monocytes and $\mathrm{T}$ cells from patients with indeterminate and cardiac Chagas' disease. Infect Immun 75: 1886-1894.

Talvani A, Ribeiro CS, Aliberti JC, Michailowsky V, Santos PV, Murta SM, Romanha AJ, Almeida IC, Farber J, Lannes-Vieira J, Silva JS, Gazzinelli RT 2000. Kinetics of cytokine gene expression in experimental chagasic cardiomyopathy: tissue parasitism and endogenous IFN-gamma as important determinants of chemokine mRNA expression during infection with Trypanosoma cruzi. Microbes Infect 2: 851-866.

Tanowitz HB, Burns ER, Sinha AK, Kahn NN, Morris SA, Factor SM, Hatcher VB, Bilezikian JP, Baum SG, Wittner M 1990. Enhanced platelet adherence and aggregation in Chagas' disease: a potential pathogenic mechanism for cardiomyopathy. Am J Trop Med Hyg 43: 274-281.

Tanowitz HB, Huang H, Jelicks LA, Chandra M, Loredo ML, Weiss LM, Factor SM, Shtutin V, Mukherjee S, Kitsis RN, Christ GJ, Wittner M, Shirani J, Kisanuki YY, Yanagisawa M 2005. Role of endothelin 1 in the pathogenesis of chronic chagasic heart disease. Infect Immun 73: 2496-2503.

Tarleton RL 2003. Chagas disease: a role for autoimmunity. Trends Parasitol 19: 447-451.

Tarleton RL, Sun J, Zhang L, Postan M 1994. Depletion of T-cell subpopulations results in exacerbation of myocarditis and parasitism in experimental Chagas' disease. Infect Immun 62: 1820-1829.

Tibayrenc M, Ayala FJ 1987. Trypanosoma cruzi populations: more clonal than sexual. Parasitol Today 3: 189-190.

Todeschini AR, Girard MF, Wieruszeski JM, Nunes MP, Dos Reis GA, Mendonca-Previato L, Previato JO 2002a. Trans-sialidase from Trypanosoma cruzi binds host T-lymphocytes in a lectin manner. J Biol Chem 277: 45962-45968.

Todeschini AR, Nunes MP, Pires RS, Lopes MF, Previato JO, Mendonça-Previato L, Dos Reis GA 2002b. Costimulation of host T lymphocytes by a trypanosomal trans-sialidase: involvement of CD43 signaling. J Immunol 168: 5192-5198.

Todorov AG, Andrade D, Pesquero JB, Araujo Rde C, Bader M, Stewart J, Gera L, Müller-Esterl W, Morandi V, Goldenberg RC, Neto HC, Scharfstein J 2003. Trypanosoma cruzi induces edematogen- ic responses in mice and invades cardiomyocytes and endothelial cells in vitro by activating distinct kinin receptor (B1/B2) subtypes. FASEB J 17: 73-75.

Turner D, Grant SC, Yonan N, Sheldon S, Dyer PA, Sinnott PJ, Hutchinson IV 1997a. Cytokine gene polymorphism and heart transplant rejection. Transplantation 64: 776-779.

Turner DM, Williams DM, Sankaran D, Lazarus M, Sinnott PJ, Hutchinson IV 1997b. An investigation of polymorphism in the interleukin-10 gene promoter. Eur J Immunogenet 24: 1-8.

Tzelepis F, de Alencar BC, Penido ML, Claser C, Machado AV, Bruna-Romero O, Gazzinelli RT, Rodrigues MM 2008. Infection with Trypanosoma cruzi restricts the repertoire of parasitespecific $\mathrm{CD}^{+} \mathrm{T}$ cells leading to immunodominance. J Immunol 180: $1737-1748$.

Vago AR, Andrade LO, Leite AA, d'Avila Reis D, Macedo AM, Adad SJ, Tostes S Jr, Moreira MC, Filho GB, Pena SD 2000. Genetic characterization of Trypanosoma cruzi directly from tissues of patients with chronic Chagas disease: differential distribution of genetic types into diverse organs. Am J Pathol 156: 1805-1809.

Vago AR, Macedo AM, Oliveira RP, Andrade LO, Chiari E, Galvão LM, Reis D, Pereira ME, Simpson AJ, Tostes S, Pena SD 1996. Kinetoplast DNA signatures of Trypanosoma cruzi strains obtained directly from infected tissues. Am J Pathol 149: 2153-2159.

Venegas J, Coñoepan W, Pichuantes S, Miranda S, Apt W, Arribada A, Zulantay I, Coronado X, Rodriguez J, Reyes E, Solari A, Sanchez G 2009. Differential distribution of Trypanosoma cruzi clones in human chronic chagasic cardiopathic and non-cardiopathic individuals Acta Trop 109: 187-193.

Villalta F, Zhang Y, Bibb KE, Kappes JC, Lima MF 1998. The cysteine-cysteine family of chemokines RANTES, MIP-1alpha, and MIP-1beta induce trypanocidal activity in human macrophages via nitric oxide. Infect Immun 66: 4690-4695.

Wizel B, Nunes M, Tarleton RL 1997. Identification of Trypanosoma cruzi trans-sialidase family members as targets of protective CD8 ${ }^{+}$TC1 responses. J Immunol 159: 6120-6130.

Wizel B, Palmieri M, Mendoza C, Arana B, Sidney J, Sette A, Tarleton R 1998. Human infection with Trypanosoma cruzi induces parasite antigen-specific cytotoxic $\mathrm{T}$ lymphocyte responses. J Clin Invest 102: 1062-1071.

Zhang L, Tarleton RL 1996. Persistent production of inflammatory and anti-inflammatory cytokines and associated $\mathrm{MHC}$ and adhesion molecule expression at the site of infection and disease in experimental Trypanosoma cruzi infections. Exp Parasitol 84: 203-213.

Zingales B, Stolf BS, Souto RP, Fernandes O, Briones MR 1999. Epidemiology, biochemistry and evolution of Trypanosoma cruzi lineages based on ribosomal RNA sequences. Mem Inst Oswaldo Cruz 94 (Suppl. I): 159-164. 